\title{
フィルム冷却によるデュアルベルノズルの運転モード遷移の制御*1 Control of Operation Mode Transition with Film Cooling in Dual-Bell Nozzles
}

\author{
Proshchanka, Dzianis ${ }^{* 2} \cdot$ 米 澤 宏 一 $* 2$-古賀 英 和 $* 2 \cdot$ 佃 宏 明*2 \\ Dzianis Proshchanka, Koichi Yonezawa, Hidekazu Koga, Hiroaki Tsukuda, \\ 辻 本 良 信 ${ }^{* 2} \cdot$ 木 村竜 也*3 $\cdot$ 横 田和 彦*4 $\cdot$ PASINI, Angelo*5 \\ Yoshinobu Tsujimoto, Tatsuya Kimura, Kazuhiko Yokota and Angelo PAsini
}

Key Words : Dual Bell Nozzle, Shock Wave, Separation

\begin{abstract}
Dual-bell nozzle is one of the altitude compensation nozzle concepts, which consists of two bell-type nozzle with different geometric area ratios. The dual bell nozzle has two operation modes - a low altitude operation mode and a high altitude operation mode. However, the practical transition between these operation modes occurs at lower nozzle pressure ratio (NPR) than the optimum one. In the present study, the effect of introduction of film-cooling flow into the nozzle is examined in order to control the operation mode transition NPR. The experimental and numerical results show that the operation mode transition can be control by injecting the film cooling flow at appropriate inlet pressure and flow rate. By injecting the film cooling flow, the axial momentum near the wall in the extension part becomes small and the separation point movement becomes slower. As a result, the dip of the thrust coefficient during the operation mode transition becomes smaller.
\end{abstract}

\section{1. 緒訔}

ロケット打上げ時から, 背圧がほぼ 0 となる高高度まで の, 広い範囲で利用できる高度補償型のロケットノズルの 一つとしてデュアルベルノズルが考案されている1). デュ アルベルノズルは第 1 図に示すように, 低膨張比のベース ノズル部と高膨張比のエクステンション部からなり，2つ のノズルの接続点では壁面勾配が不連続となっている. 打 上げ時から低高度においてはベースノズルにおいて飛行に 必要な推力を発生させ, 接続点で燃焼ガスを軸対称に安定 して剥離させることで, NPR（Nozzle Pressure Ratio= (ノズル入口全圧) /(ノズルの背圧)）が比較的小さな状態で も, ロケットの安定した飛行を可能にしている. 一方, ロ ケットの周囲がほぼ真空に近い高高度においては, ノズル 内部での燃焼ガスの剝離が発生しなくなるので, 膨張比が 大きなエクステンション部の効果により長時間の飛行を行 うのに必要な大きな比推力を得ることができる。このため, コスト面などで多段式に比べて有利な単段ロケットや, 宇 宙往還型の再使用ロケットなどへの応用が期待されている. 一方, 同様な高度補償ノズルとして, 伸展型ノズルやエア ロスパイクノズルなども実用化に向けて研究が行われてい る.しかし進展型ノズルはエンジン運転中でのノズルの進

\footnotetext{
*1 (C) 2011 日本航空宇宙学会

平成 23 年 4 月 26 日原稿受付

*2 大阪大学大学院基礎工学研究科

*3 三菱重工業 (株) 名古屋誘導推進システム製作所

*4 青山学院大学理工学部

*5 ピサ大学
}

展は実用上行われたことがなく，サブスケールモデル燃焼 実験では，ノズル進展時に弱い横推力と壁面の熱流束の増 加が確認されている21. エアロスパイクノズルは比推力が 最も優れている一方で重量が大きくなる問題があり, 軽量 化のための研究が行われている3). 一方, デュアルベルノズ ルは構造が単純, 比較的軽量であるなどの利点がある一方 で，第 2 図に示すように，低高度運転モードから高高度運 転モードへの遷移が, 周囲の圧力に応じて受動的に行われ るために，最適な高度で行われず，一時的に比推力が低下 するという短所が知られている4). そこで本研究では, 運 転モードの遷移高度を最適な高度に近付けるために, ノズ ル壁面の接続点からフィルム冷却流を流入させることによ り制御する方法を検討する. Martelli らはベースノズル壁 面からフィルム冷却を導入すると, 運転モード遷移時の剝 離点の移動に変化が生じることを報告しているが, 詳細な 検討はなされていない5), 一方, 著者らは CFD 解析によ り,ノズル壁面の接続点からフィルム冷却を導入すると運 転モード遷移条件の改善の可能性を示した ${ }^{6)}$. そこで本研 究では風洞試験により, これを確認し, CFD 解析と組み合 わせて, 詳細な特性とそのメカニズムを検討する。ただし, 本研究ではフィルム冷却流が主流の剝離点の挙動に及ぼす 基本的な影響を定性的に調べることを目的とし，作動流体 には常温の乾燥空気を用い, 燃焼ガスの物性や壁面冷却効 果は考慮しない.

\section{2. 実験方法および数值解析方法}

第 3 図に本研究で用いた風洞の全体図を示す。本研究で 
用いた風洞では, 上流の $1.3 \mathrm{MPa}$ の高圧タンクから, 予め 減圧した低圧タンクへ, 共試体ノズルを経て, 作動流体で ある空気を流すことでノズルの起動から停止までの流れを 再現する。な挹, 本研究では NPR が上昇する過程を「起 動」と呼び，NPR が低下する過程を「停止」と記述する。 作動流体には冷凍式乾燥機で水分を取り除いた空気を用い た。また，起動に要する時間は，主制御バルブ（空圧アク チュエータ式ボールバルブ）の作動時間により制御される. また, 試験部の側面には観察空が設けられており, シュリー レン法による流れの可視化を行うことが可能である. 本研 究では, シュリーレン法で可視化したイメージを, 高速度 ビデオカメラを用いて毎秒 13500 フレームで撮影した。

第 4 図に本研究で用いたノズルの試験部を示す．風洞の マニホールドからノズル上流の高圧室に高圧気体を供給し てノズル流れを作り出している。ノズルは上流側高圧室に 設置した 4 本のシャフトと，ノズル側面に設置したシャフ トで支持されている. 高圧室側のシャフトは軸方向のみ，ノ ズル側のシャフトは流れ方向とそれに垂直な横方向にリニ アブッシュおよびリニアガイドで支持されており, 各方向



第 1 図 デュアルベルノズルの運転モード4)

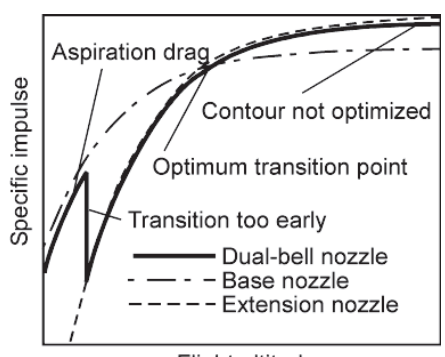

Flight altitude

第 2 図運転高度と比推力 ${ }^{4}$
の支持荷重を、ロードセルを用いて推力と横推力として計 測が可能となっている，ただし，風洞内の圧力が変化する と, 一時的にロードセル内外で圧力差が生じ, これが荷重 として出力される問題が生じた. しかし, この変動はノズ ル内部での流れの変化に比べて極めて緩やかな変化である ため, $5 \mathrm{~Hz}$ 以下の成分を取り除くことで，この影響を排除 した，一方，ノズルに静止大気中で打撃を加えて固有振動 数を計測したところ, 軸方向（推力方向）におよそ $900 \mathrm{~Hz}$, 横方向に $1200 \sim 1500 \mathrm{~Hz}$ の固有振動数が確認された。 この 固有振動数は風洞外壁の剛性に起因していると考えられる が, 本研究では, 運転モードの遷移にのみ着目しているの で, 細かい変動成分は特に問題とならないと考えたので, 推 力および横推力はロードセルの出力をそのまま示してある. な打全データのサンプリング周波数は $20 \mathrm{kHz}$ である. 本 研究では, ノズルの入口全圧を $p_{\text {in }}$ として, スロート上流 の高圧室に扔ける壁面圧力を用い，ノズル背圧は，ノズル からの流れが直接当たらない, 第 4 図中に示した試験部の 壁面圧力と定義した。ただし，試験部では背圧に多少の分 布があることが確認されているが，すべての実験について 同じ場所の圧力を用いることで, 定性的な比較は可能であ る。フィルム冷却流には風洞周辺の大気を用い, 流入圧力 は試験部側面に取り付けたボールバルブの開度により調節 した。なお，大気を作動流体に用いた場合に，凝縮等の影 響が懸念されるが，過去に同様に大気を用いた実験を行っ た場合にも，現象の性質を変化させるような大きな問題は なく7, 本研究に打いても影響は小さいと考えられる.

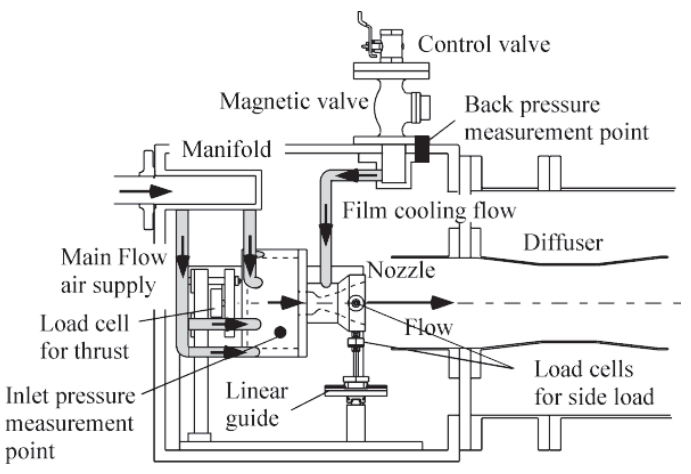

第 4 図 試験部内部の概略図

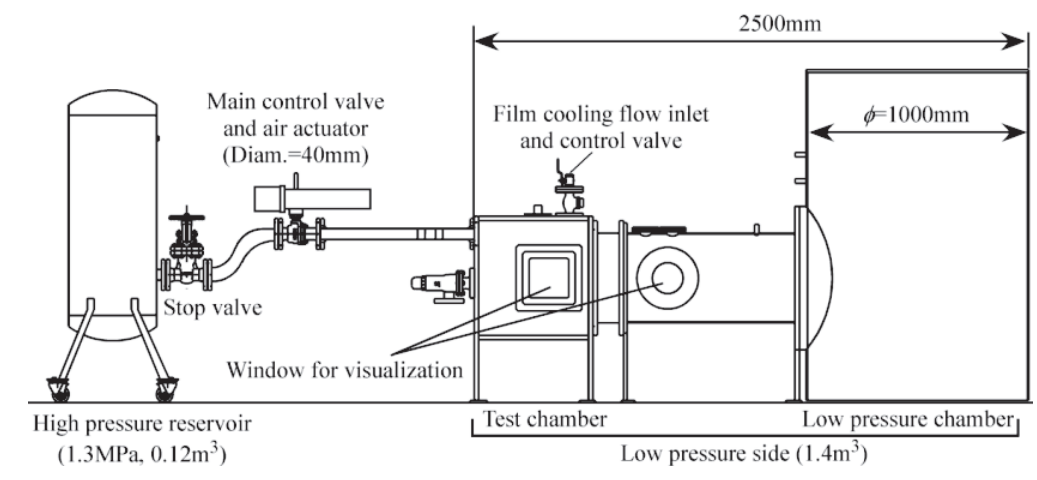

第 3 図実験用風洞の概略図 


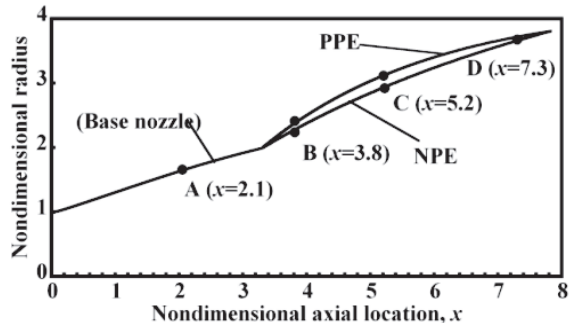

(a) 実験に用いたノズル形状と圧力計測点（寸法はスロート 半径 $10 \mathrm{~mm}$ で無次元化している)

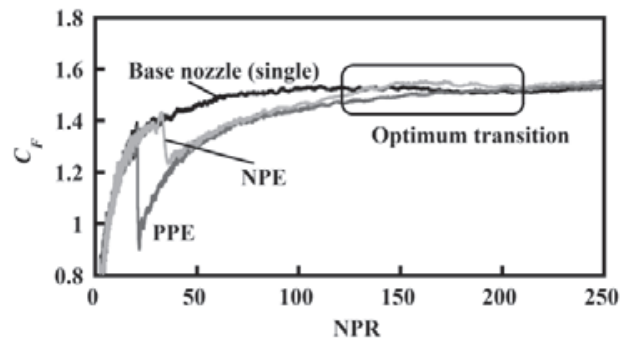

(b) 停止時における NPR に対する推力係数の変化

第 5 図 ノズル形状および推力係数

第 5 図 (a) にノズル形状と壁面圧力計測点を示す. 図の軸 の值はスロート半径 $10 \mathrm{~mm}$ で無次元化されている. 上流側 の低澎張のベースノズルにはTP (Truncated Perfect) ノズ ルを用いた. エクステンション部では, 壁面圧力が上流から 下流に向かって低下する, NPE (Negative Pressure gradient Extension）と下流に向かって上昇する PPE（Positive Pressure Gradient）の 2 形状を用いた。また，壁面圧力 計測点は軸方向に 4 点（点 $\mathrm{A} \sim \mathrm{D} ）$ 設置した．第 5 図 (b) は 2 つのデュアルベルノズルおよびベースノズルのみ（シ ングルベル）について，停止時に扔けるNPR に対する推 力倸数を示したものである. ただし，推力倸数は後述する 式 (3) で定義される。 これらを比較すると, デュアルベル ノズルの推力係数が TP ノズルの推力係数を上回っている のは NPR > 150〜170であることから， NPR =150〜170 が, 本研究で用いたデュアルベルノズルの最適な運転モー ドの遷移条件となる。しかし，実際には最適な NPRより もかなり低いNPR で運転モードが遷移し，この結果，大 きな推力低下が生じている。 また，この図からノズル形状 により運転モードの改善が可能であることが示唆されてい るが, 各運転モードでの推力の配分とノズルの大きさなど の制約下に打ける最適な形状設計法は未だ明らかとなって いない.

第 6 図にフィルム泠却流噴き出し部の形状を示す。フィ ルム冷却流は第 6 図 (a) に示すように, ノズル側面のマニ ホールドから，第 6 図 (b) に示すスリット上の噴き出し部 を経て主流へ合流する。本研究では図に示した A, Bの 2 つ の形状を用いて，形状の違いを比較した．図中の, ht, he, $h s$ はそれぞれ，フィルム泠却流入口の最小高さ，主流への 入口高さ，入口部の段差高さである。本研究で用いたノズ ルのフィルム冷却流入口形状, 寸法とノズルの名称を第 1 表にまとめる。フフルム冷却流の主流への入口面における

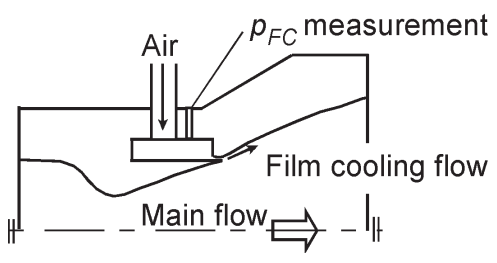

(a)ノズルの構造

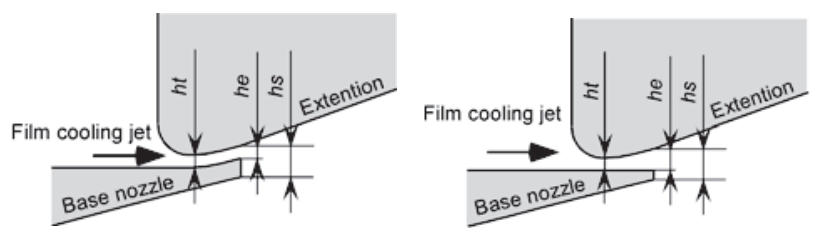

(b) フィルム冷却流入口形状 (左 : A, 右 : B)

第 6 図フィルム冷却流噴き出し部の形状

第 1 表 ノズル形状と名称

\begin{tabular}{cccccc}
\hline & \multicolumn{3}{c}{ フィルム冷却流入口 $[\mathrm{mm}]$} & \multirow{2}{*}{ ノズルの名称 } \\
\cline { 2 - 5 } & 形状 & $h t$ & $h e$ & $h s$ & \\
\hline \multirow{3}{*}{ NPE } & $\mathrm{A}$ & 0.4 & 0.4 & 1.0 & NPE_A10 \\
& $\mathrm{A}$ & 1.1 & 1.1 & 1.7 & NPE_A17 \\
& $\mathrm{B}$ & 0.4 & 0.7 & 1.0 & NPE_B10 \\
\hline \multirow{3}{*}{ PPE } & $\mathrm{A}$ & 0.4 & 0.4 & 1.0 & PPE_A10 \\
& $\mathrm{A}$ & 1.1 & 1.1 & 1.7 & PPE_A17 \\
& $\mathrm{B}$ & 0.4 & 0.7 & 1.0 & PPE_B10 \\
\hline
\end{tabular}

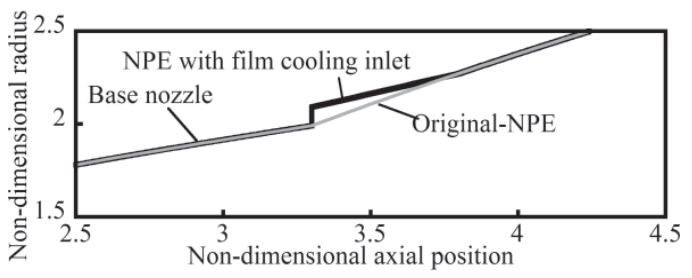

(a) 段差高さ $1 \mathrm{~mm}$

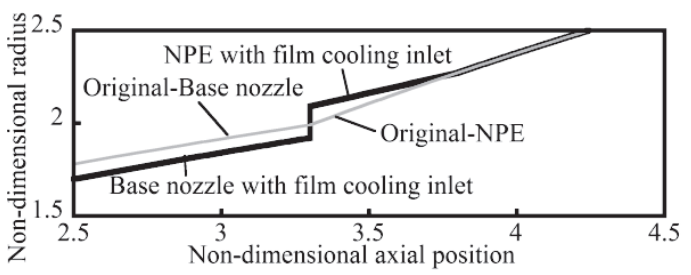

(b) 段差高さ $1.7 \mathrm{~mm}$

第 7 図 オリジナル形状およびフィルム冷却噴き出し部を設けた場合 の接続点近傍のノズル形状

流入マッハ数はエクステンションの形状にかかわらず, $\mathrm{A} 10$ ノズルおよび $\mathrm{A} 17$ ノズルでは $1.1, \mathrm{~B} 10$ ノズルでは 1.8 1.9 である。 なお，フィルム冷却流の入口全圧 $p_{\mathrm{FC}}$ は第 6 図 (a)に示すように, ノズル側面マニホールドの壁面圧力 と定義する.

第 7 図にNPEノズルにフィルム冷却流噴き出し部を設け た場合の接続点近傍のノズル形状を示す，段差高さ $1.0 \mathrm{~mm}$ の場合にはエクステンション部の一部を切り取る形で段差 状の入口を設けた. 一方, 段差高さ $1.7 \mathrm{~mm}$ の場合にはべー スノズルを $0.7 \mathrm{~mm}$ 内側に平行移動した。このため,オリ 
ジナル形状および段差高さ $1.0 \mathrm{~mm}$ ではべースノズルの膨 張比は 4.0 であるが, 段差高さ $1.7 \mathrm{~mm}$ では, ベースノズ ルの膨張比は 4.3 となり膨張比が大きな分, 遷移時の NPR が大きくなる可能性があるが, 後述のように影響は小さく, 膨張比の違いは考えない. PPEノズルについても同様な形 状を用いた。

本研究ではノズル内部流れを調べるために，NPE_A10 ノズルと PPE_A10 ノズルについて，CFD 解析を行った。 第 8 図に計算領域の模式図と NPE_A10 ノズル周辺および フィルム冷却流入口周辺の計算格子を示す. 計算領域は周 方向に一様な流れを仮定した 2 次元円筒座標系にノズルと 外部領域を設定した。実験装置ではノズル周辺は軸対称形 状とはなっていないが, 簡単のため, 風洞の下流ダクト寸 法と同程度の半径と長さの領域を設けた。 また, ノズル下 流のディフューザも考慮していない．計算格子は軸方向に 600 点（うち, ノズル内部に 450 点）, 半径方向に 150 点 で分割した，また，フィルム冷却流の吹き込み口には軸方 向に 100 点, 半径方向に 8 点, 配置した。 なお, 計算格子 については格子点数を各方向に 1.5 倍, 全体で 2.25 倍して も結果に違いはほとんど見られなかった。

CFD 解析は作動流体に空気を理想気体として用い, 軸 対称流れを仮定した円筒座標系における 2 次元の連続の 式，Navier-Stokes 方程式，エネルギ式を有限差分法に基 づいて離散化して行った. 対流項は, 基本変数を 2 次精度 の MUSCL 法で内挿して AUSMDV 8) を用いて求めた. 粘 性項は 2 次精度中心差分で離散化した。時間進行は陰解法 により行い, 時間項を 3 点後退差分で離散化し, LU-SGS 法9)を用いた内部反復を各時間ステップで行った，乱流モ デルにはSpalart-Allmaras モデル10)を用いた，入口境界 条件では, 入口全圧を後述のように与え，入口全温を $293 \mathrm{~K}$ に固定して, 隣接格子点から Riemann 不変量を外挿し, 各 基本変数を求めた。出口境界においては静圧を与え, 密度 と各速度成分を外挿した。壁面では断熱・non-slip 条件を 課した。なお，本研究で用いた解析コードは，これまでに も超音速ノズル内部の剝離流れに関する解析に用いられて

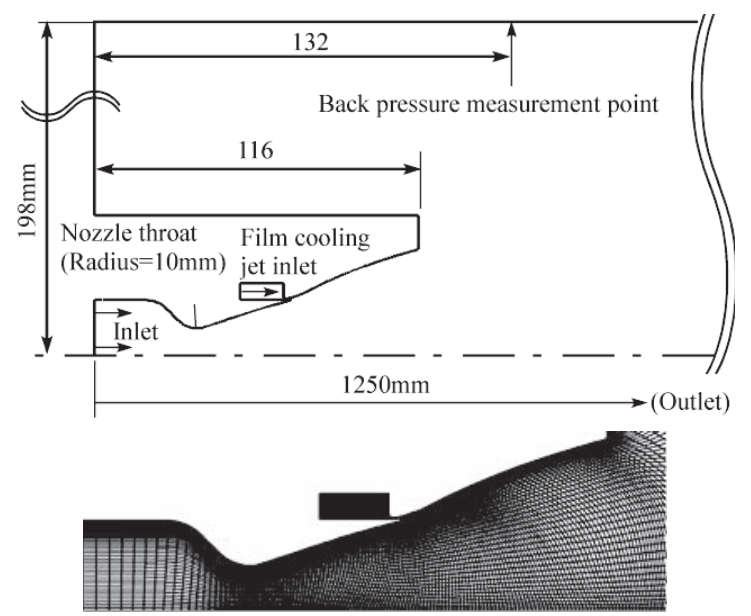

第 8 図計算領域（上図）と計算格子（下図, 格子線は 4 本ごとに 表示)
おり，実験結果との比較による妥当性の検証が行われてい $る^{7)}$.

本研究で行った実験や CFD 解析は, 起動時, および停 止時について行ったが, 停止時については, 圧力比などの 值は異なるものの, 現象の基本的な性質は起動時と同様で, 逆の順序で生じていた。そこで本報では起動時の結果のみ を示すこととする．停止時の結果については一部を別報11) で示しているので参照されたい.

\section{3. 結果と考察}

本研究では主流, フィルム冷却流の流入条件を規定する ため, それぞれの入口全圧と背圧を用いて NPR を次式に 示すように定義した。

$$
\begin{aligned}
& \mathrm{NPR}=p_{\text {in }} / p_{\mathrm{b}} \\
& \mathrm{NPR}_{\mathrm{FC}}=p_{\mathrm{FC}} / p_{\mathrm{b}}
\end{aligned}
$$

推力係数および横推力係数を以下のように定義する.

$$
\begin{aligned}
& C_{\mathrm{F}}=\text { Thrust } /\left(p_{\text {in }} \cdot A^{*}+p_{\mathrm{FC}} \cdot A_{\mathrm{FC}}^{*}\right) \\
& C_{\mathrm{SL}}=\operatorname{SideLoad} /\left(p_{\text {in }} \cdot A^{*}+p_{\mathrm{FC}} \cdot A_{\mathrm{FC}}^{*}\right)
\end{aligned}
$$

ただし， $p_{\mathrm{in}}, p_{\mathrm{FC}}, p_{\mathrm{b}}$ はそれぞれ，ノズル入口全圧，フィ ルム冷却流入口全圧, ノズルの背圧であり， $A^{*}, A_{\mathrm{FC}}^{*}$ は ノズルスロート断面積, フィルム冷却流入口部最小断面積 である。またフィルム冷却流を用いない場合には $p_{\mathrm{FC}}=0$ とする。

第 9 図にオリジナル形状の NPEノズルおよび PPE ノ ズルの，ノズル内部に剥離が生じていない NPR = 100 に おける壁面圧力分布の計測結果と CFD 結果との比較を示 す.この図から, 剝離がない場合の壁面圧力分布について は実験結果と CFD 結果はほぼ一致していることがわかる. また，エクステンション部においては，NPEノズルの壁 面圧力勾配は下流に向かって負であり, PPEノズルは正と なっていることが確認できる. また, 第 2 表に示した結果 は, 実験において背圧を可能な限り小さくして計測した最 大推力係数と, CFDによる真空中推力係数の予測值との 比較であるが, これらもほぼ一致した結果が得られている. また NPE/PPE 両ノズルの推力係数の最大值については, ほほ同じであることが確認できる。

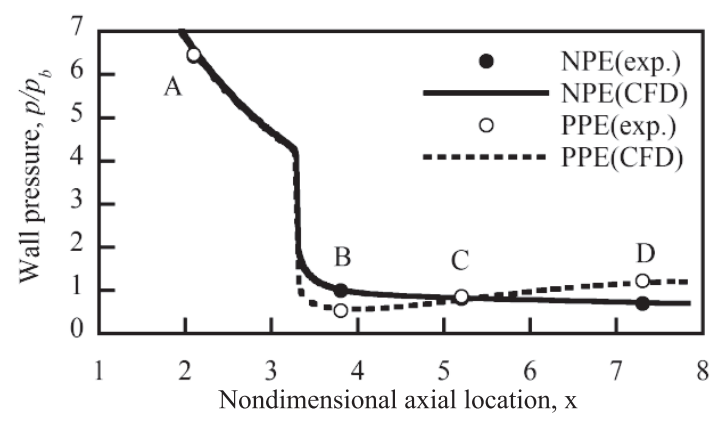

第 9 図 壁面圧力分布 $(\mathrm{NPR}=100)$ 

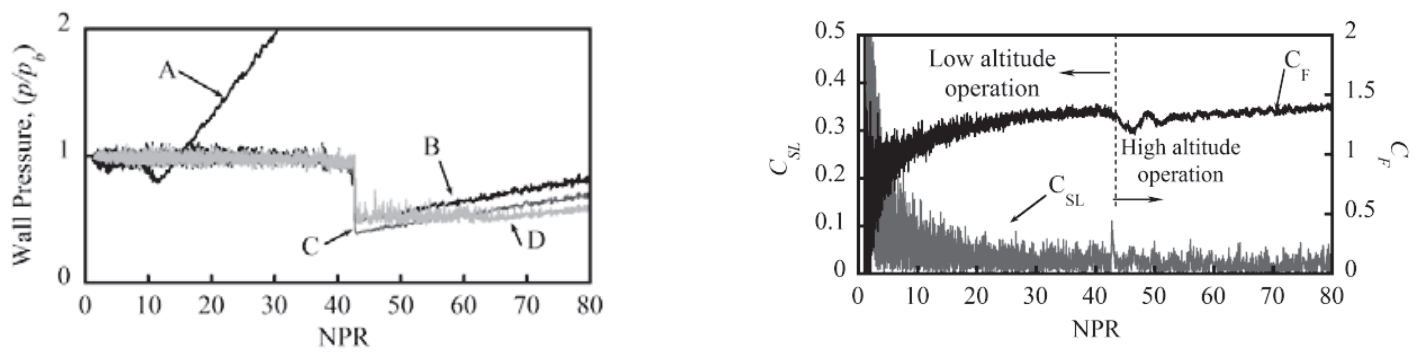

(a) NPEノズル
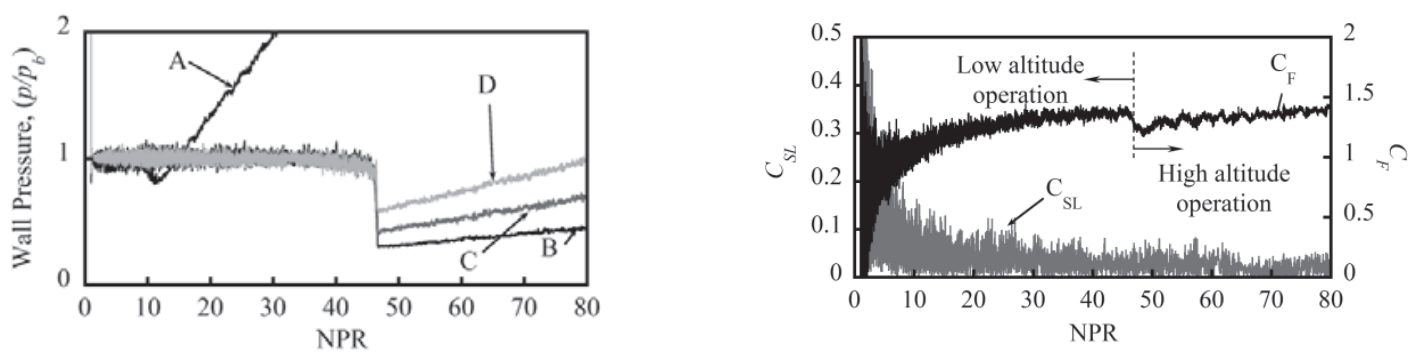

(b) PPEノズル

第 10 図 オリジナル形状の実験結果（左：壁面圧力変動, 右：推力係数㧍よび横推力係数）

第 2 表 推力係数の比較

\begin{tabular}{lcc}
\hline & 3-D NPE & 3-D PPE \\
\hline 計測結果 (NPR > 500) & 1.6 & 1.6 \\
CFD (真空放出) & 1.6 & 1.6 \\
\hline
\end{tabular}

第 10 図に NPE/PPEノズルのそれぞれの起動時におけ る, 壁面圧力, 推力係数, 横推力係数の計測結果を NPRに 対して示す。この時の入口圧力は, $4 \mathrm{kPa}$ から約 $900 \mathrm{kPa} / \mathrm{s}$ で上昇させ，背圧は約 $4 \mathrm{kPa}$ で一定であった。起動時の NPR の上昇率については, 実験で可能な範囲で検討を行ったが, これよりも 1.5 程度大きな増加率でも，ほぼ同様な結果が 得られており, 剝離点の移動に対して, NPRの上昇率の影 響は小さいと考えられる。結果を見ると，まず，NPEノズ ルについては, 剝離点は, およそ $\mathrm{NPR}=10$ に計測点 $\mathrm{A}$ を 通過した後, 接続点でしばらく移動が停滞した後, NPR= 43 で点 $\mathrm{B} \sim \mathrm{C}$ をほぼ同時に通過する。一方, 点 D でも点 B，Cとほぼ同時に圧力が急低下するが，急低下直後では点 $\mathrm{B}$ での圧力とほぼ等しく, $\mathrm{NPR}=65$ までは圧力はほとん ど変化せず，点 $\mathrm{C}$ の圧力を下回る. その後, 他の計測点と 同様に NPR の増加とともに圧力が増加している。 つまり, 剝離点は, 運転モードの遷移開始時に接続点から点 D のや や上流まで急激に移動し, その後 NPRの上昇とともに徐々 に下流へ移動し, 点 Dを通過していると考えられる。した がって NPR = 43 から 65 にかけて低高度運転から高高度 運転に遷移したことになる。一方, PPEノズルでは NPR $=47$ において, 剝離点はほぼ同時に圧力計測点 $\mathrm{B} \sim \mathrm{D}$ を通

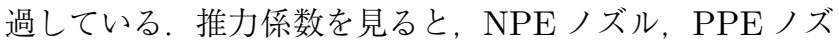
ルともに運転モードの遷移時で, 推力係数が極小值となっ ていることが確認できる。また，NPEの遷移時には横推力 が大きくなっていることが確認できる。なお， NPR $=10$ 付近では周期的な流体振動による横推力 ${ }^{6,12)}, \mathrm{NPR}<5$ で は噴流のスロート剝離による不規則な横推力がともに比較
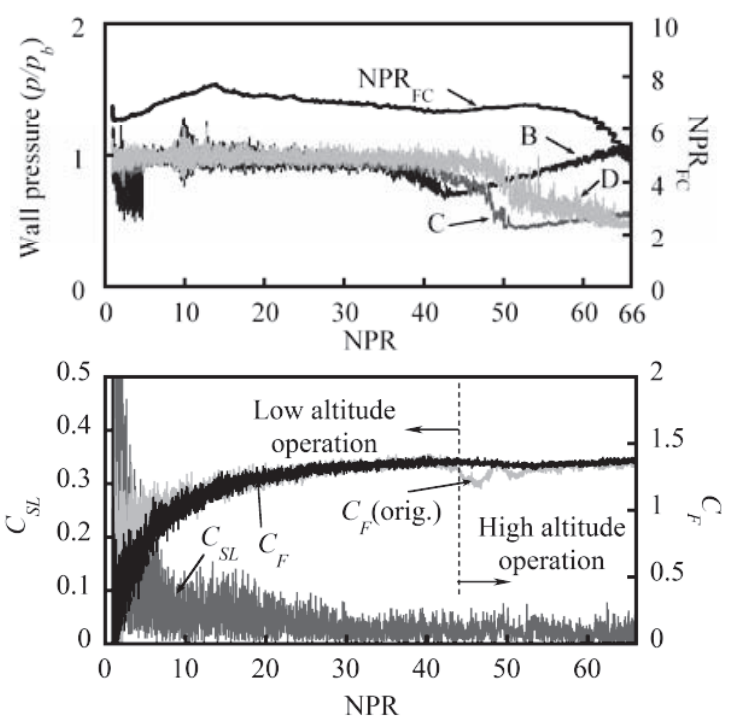

第11図 NPE_A10 ノズル $\left(p_{\mathrm{FC}}=30\right)$ の実験結果（上：壁面圧力 および $\mathrm{NPR}_{\mathrm{FC}}$, 下：推力係数㧍よび横推力係数)

的大きな振幅を伴って発生している.

第 11 図にNPE_A10ノズルにおいてフィルム冷却流を 流入させた場合の実験結果を示す。フィルム冷却流の実験 においては, 入口圧力は $4 \mathrm{kPa}$ から $120 \mathrm{kPa} / \mathrm{s}$ で上昇させ, 背圧は約 $4 \mathrm{kPa}$ から $6 \mathrm{kPa}$ に変化した。実験ではフィルム 冷却流入口圧力を $p_{\mathrm{FC}}=70 \mathrm{kPa}$ までの範囲で実験を行い 比較したが, ここでは紙面の都合上, 推力係数の落ち込み が最も小さかった場合の $p_{\mathrm{FC}}=30 \mathrm{kPa}$ の結果を示してい る。また, フィルム冷却流の質量流量は $p_{\mathrm{FC}}=70 \mathrm{kPa}$ の ときに高高度運転時には $5 \%$ 未満であることが $\mathrm{CFD}$ 解析 や 1 次元の等エントロピ流れの関係式から確認された。な お, $\mathrm{NPR}_{\mathrm{FC}}>2.2$ での実験を行っているため, フィルム冷 却流はチョークしている.この図では $\mathrm{NPR}_{\mathrm{FC}}$ は背圧の変 
動とともに，やや変化しているが，拉よそ $\mathrm{NPR}=40$ か ら $\mathrm{NPR}=65$ にかけて遷移が生じていることがわかる．第 10 図 (a)に示したNPEオリジナル形状と比較すると, 壁 面圧力の変化から, 遷移が始まるNPR はフィルム冷却流 の有無にかかわらず $\mathrm{NPR}=40$ 程度で, ほとんど変化がな い. しかし, 剝離点の移動はオリジナル形状の場合と比べ て, 緩やかで広範囲の NPR にわたって徐々に行われてい る.このため, 壁面圧力の低下量が小さくなり, 推力係数 の低下が小さくなっていると考えられる。 また，横推力に ついてもオリジナル形状の場合よりも小さくなった，従来 の研究例では, モードの遷移に要する時間が長いと, 流れ が非対称になる時間が長く, 横推力が増加する傾向がある とされているが, 本研究で複数回行った実験ではいずれの 場合も大きな横推力は観察されなかった。 また, フィルム 冷却流を加えたことで, 起動時㧍よび停止時ともに NPR $=10$ 付近でオリジナル形状よりも強い圧力変動が確認でき る.この圧力変動は周期的で㧍よそ $1250 \mathrm{~Hz}$ の周波数でほ ぼ軸対称に振動していた。オリジナル形状でも同様な流体 振動が観察されているが6,12), フィルム冷却流を加えるこ とで振幅が著しく増加している，流体振動は, 機体や様々 な要素の振動問題の原因となり得るので, 今後, この振動 のメカニズムや特性を明らかにする必要がある.

ここで, 遷移時の剝離点の動きが緩やかであるにもかかわ らず大きな横推力が生じないという, 従来の知見と異なった 結果が得られた原因に関しては, 今後, 3 次元非定常 CFD 解析などにより確認する必要があるが, 現時点で以下のよ うに考えられる。まず，第 10 図 (a) の遷移前の低高度運転 モードではNPR が大きくなるほど横推力が小さくなって いる. 特に NPR $=10$ 付近では周期的な流体振動が生じ るが, この流体振動によるノズル壁面圧力変動はNPR の 上昇とともに小さくなる6,7).つまり低高度運転モードにお いては NPR が大きくなるほどジェットが安定する性質が あると言える。したがって, フィルム泠却流を加えること で遷移時の NPR が高 NPR 側にシフトするため, 剝離点 がエクステンション部を移動する際にジェットが安定であ るため, 大きな横推力が発生しなかったものと考えられる.

一方, PPEノズルについては, 紙面の都合上図は示さな いが，後述のように運転モードの遷移が生じるNPRにや や変化が見られたが, 剝離点がほぼ同時に点 $\mathrm{B} \sim \mathrm{D}$ を通過 することや，推力係数の落ち込みも同様に観察されており， NPEで見られたような大きな影響は観察されなかった。

第 12 図に，フィルム泠却の流入条件 $p_{\mathrm{FC}}$ を変化させた 場合の NPEノズル抢よびPPEノズルそれぞれに打ける運 転モードの遷移時に剝離点が各計測点を通過するNPR と, $\mathrm{NPR}_{\mathrm{FC}}$ との関倸を示す. NPEの図では各実験について計 測結果を線でつないで拈り, NPRが小さな順に点 B から D を剝離点が通過した条件を示している.PPEでは運転モー

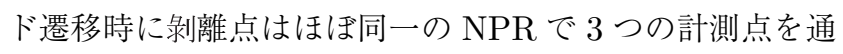
過したため, 各実験結果は 1 点で表されている。剝離点は まず, 第 6 図に示した段差の高さ $h s$ が $1.0 \mathrm{~mm}$ で共通で, 噴き出し部の形状が異なる NPE_A10 と NPE_B10 につい
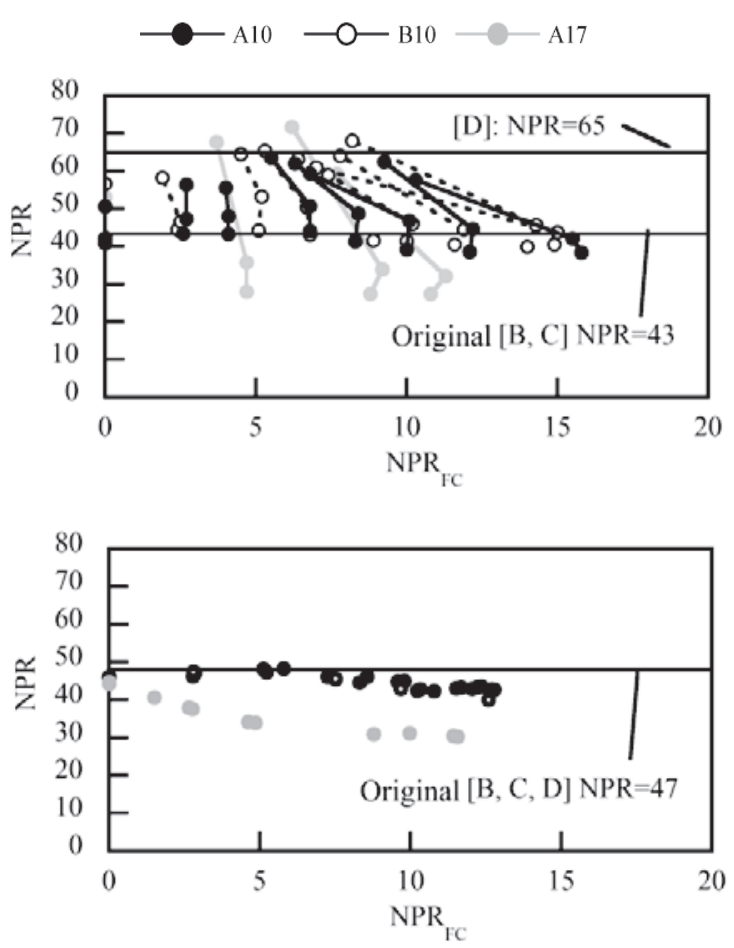

第 12 図各圧力計測点における剝離点通過時の $\mathrm{NPR}_{\mathrm{FC}}$ と NPR の 関係（実験，上：NPE，下：PPE，水平線はオリジナル形 状の值)

て比較すると, NPE，PPEともに噴き出し部の形状の違 いによる影響はほとんど見られない，一方，NPE_A17や PPE_A17では，オリジナル形状よりも低いNPRで剝離点 が計測点 $\mathrm{B}, \mathrm{C}$ を通過しており, この結果, 推力係数の落ち 込みも大きくなり, 逆効果となっている. 次にエクステン ション部の形状の影響を比較する。まず，NPE_A10では 運転モードの遷移に伴う推力係数が最も小さくなる NPR と点 C を剝離点が通過するNPRがほぼ一致していたため, 特に点 $\mathrm{C}$ を剝離点が通過する NPR に着目する。フフルム 冷却を加えない場合 $\left(\mathrm{NPR}_{\mathrm{FC}}=0\right)$ には, オリジナル形状 とほぼ同じ NPR で剥離点が点 $\mathrm{C}$ を通過している。フィル 厶冷却流を加えると, 点 Cを剝離点が通過する NPR が上 昇している。しかし，この効果は最大值となる点（最適条 件）が存在し，これ以上 $\mathrm{NPR}_{\mathrm{FC}}$ を大きくしすぎると，点 $\mathrm{C}$ を剝離点が通過する NPR が小さくなっている. PPE） ズルについては, 運転モードの遷移がほぼ 1 点で表されて いる.PPE_A10 およびPPE_B10ではPPEオリジナル形 状よりわずかに遷移が生じる NPR が大きくなっている部 分が見られるが, 推力係数の落ち込みを減少させる効果は ほとんど見られなかった．また， $\mathrm{NPR}_{\mathrm{FC}}$ が大きなときに は運転モードの遷移がオリジナル形状よりも低下している.

次に NPE ノズル, NPE_A10ノズル，PPEノズル， PPE_A10ノズルの起動時についてCFD 解析を行い, フィ ルム冷却流が流れに及ぼす影響とそのメカニズムを考察し た。まず，第 13 図において NPEノズル抢よびPPEノズ ルの起動時に扔ける壁面圧力と推力倸数の NPR に対する 変化を示す. CFD 解析では実験と近い条件になるように背 

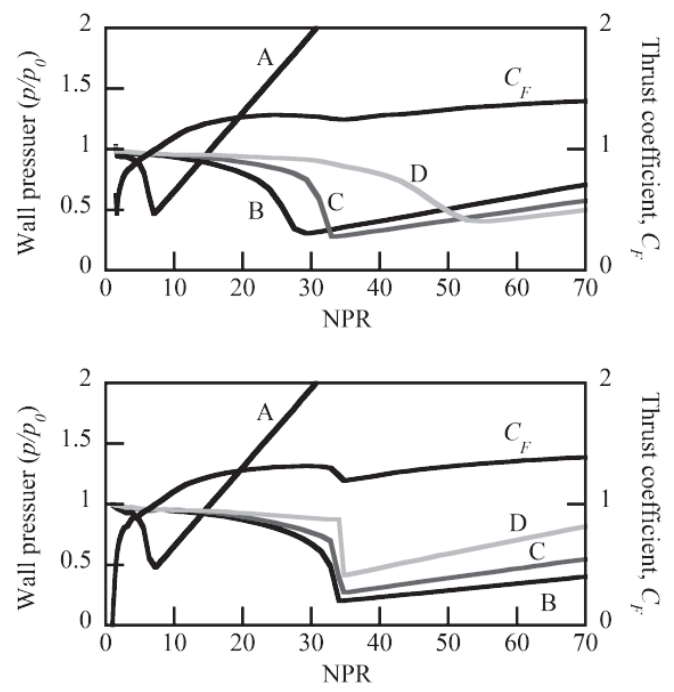

第 13 図 壁面圧力および推力係数 $(\mathrm{CFD}$, 上：NPE, 下：PPE）

圧を境界条件で与えたが, 計算ではノズル下流のディフュー ザを設けていないため，背圧值が実験值よりも 1.5 倍程度 大きくなったので, CFD では入口全圧を大きくとることで NPR をそろえた。なお，圧力の条件が異なるとレイノルズ 数が異なるが，等エントロピ過程を仮定したときのスロー 卜に打ける流速とスロート直径を用いた場合, $N P R=80$ に打ける実験条件では $R e=1.5 \times 10^{6}, \mathrm{CFD}$ 条件では $R e$ $=2.4 \times 10^{6}$ と, 共に十分大きく, レイノルズ数の影響は 小さいと考えられる。 また, CFD 解析では計算時間短縮の ため, 入口圧力の増加率を $2300 \mathrm{kPa} / \mathrm{s}$ とした。これにつ いては, フィルム冷却流がある場合も含めていくつかの条 件で実験と同程度の入口増加率での計算結果と比較したが, 計算結果はほとんど変化しなかった。第 13 図の運転モード の遷移に着目すると, NPEノズルの CFD 解析結果では, およそ $\mathrm{NPR}=27$ で計測点 $\mathrm{B}$ を通過し, $\mathrm{NPR}=33$ で点 $\mathrm{C}, \mathrm{NPR}=52$ で計測点 $\mathrm{D}$ を通過しており, 剝離点の動き は第 10 図に示した実験に比べて全体的に低いNPR で発生 し, 点 $\mathrm{B}$ から点 $\mathrm{C} へ の$ 移動もやや緩やかに行われている と言える。一方, PPEについては, 運転モードの遷移時に 剝離点がエクステンション部を瞬間的に移動する様子は捉 えられているが，遷移が生じる NPR が実験結果よりも小 さい.この問題については, 前述のように計算格子を約 2 倍に増やす, 乱流モデルを, Spalart-Allmaras モデルの代 わりにSST モデル13) に変更するなど検討を行ったが，大 きな改善は見られなかった。一方, 別な要因として過去に Stark ${ }^{14)}$ が示したように, 作動流体の凝縮が影響してい る可能性が考えられるが，シュリーレン法によるノズル外 部の可視化結果からは, 凝縮は観察されなかった。 したがっ て, 乱流モデルの定数のチューニングなどが必要かもしれ ない. しかし，全体的に遷移が生じるNPR が低いことを 除けば，NPEノズルでは剝離点が通過するNPR の值の点 $\mathrm{B}$ と点 $\mathrm{C}$ との間隔に比べて点 $\mathrm{C}$ と点 $\mathrm{D}$ との間隔が大きい こと, PPEにおいては瞬時に剝離点がエクステンション部 を通過する挙動が捉えられている。
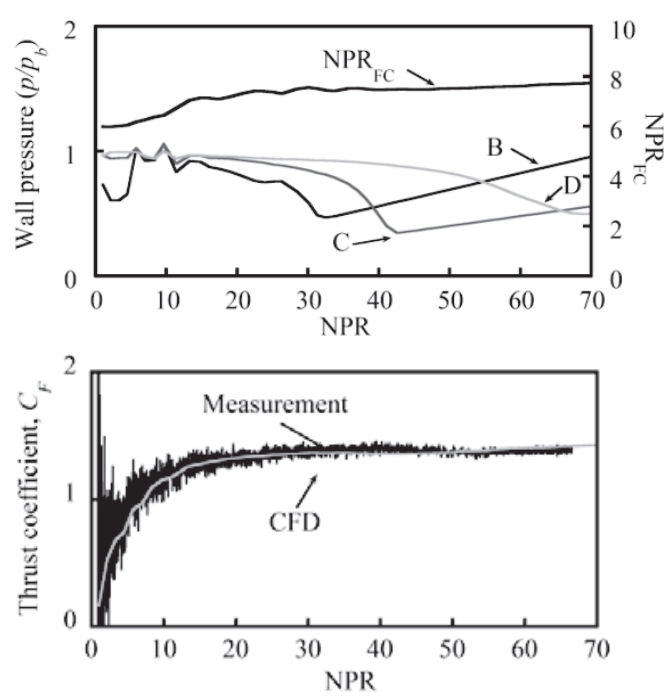

第14図 NPE_A10ノズルの CFD 解析結果（上：壁面圧力, 下：推 力係数)

第 14 図にNPE_A10 ノズルの壁面圧力の NPR に対する 変化を示す，CFDに抏いても，NPR は実験より低くなっ ているが, 実験結果と同様にオリジナル形状での計算結果 と比べて剝離点の移動がさらに緩やかとなっていることが 確認できる， $C_{\mathrm{F}}$ についてもフィルム冷却流を加えると運 転モードの遷移時に生じる一時的な $C_{\mathrm{F}}$ の低下がほとんど 見られない.

NPE_A10 と PPE_A10 の CFD 解析で得られた運転 モード遷移時に剝離点が計測点 $\mathrm{B} \sim \mathrm{D}$ を通過する NPR と $\mathrm{NPR}_{\mathrm{FC}}$ との関係を第 15 図に示す，実験と同様にNPE_A10 ではフィルム冷却流を流入させることで, 剝離点が点 $\mathrm{C}$ を通 過する NPR を増加させる効果が見られる。一方PPE_A10 では実験同様，NPEに比べて変化が小さい．

以上のように，実験と CFD を比較した場合には，CFD では実験よりも，運転モードが遷移するNPR が全体とし て低 NPR 側にずれているが, 実験で観察された現象の傾 向はほとんどを捉えており，結果を定性的に議論する上で は大きな問題とはならないと考えられる。

第 16 図はNPEオリジナル形状掞よび 2 通りの $p_{\mathrm{FC}} に$ ついての NPR_A10ノズルの壁面の接続点近傍の圧力分布 と運動量ベクトル $\left([\rho u, \rho v]^{\mathrm{T}}\right.$, ただし $\rho$ は密度, $u, v$ は 軸方向㧍よび半径方向速度) である，すべて $\mathrm{NPR}=20$ で 低高度運転モードでの状態である。まず，第 16 図 (a) に示 すオリジナル形状に扔ける流れ場を見ると, 剝離点は接続 点で生じている膨張扇中心のやや下流であることがわかる. つまり, 接続点で生じた, 強い逆圧力勾配によって剥離が 生じていることがわかる. NPR が上昇すると, 剝離点上流 の圧力が上昇し, また主流の膨張とともに剝離点下流の逆 流領域内部の圧力が低下するために, 剝離点前後の圧力バ ランスの変化に従って剝離点が下流へ移動する。第 16 図 (b) に示す, $p_{\mathrm{FC}}=20 \mathrm{kPa}$ でフィルム冷却流を加えた場合 には，第 15 図で見たように，蠡離点が圧力計測点 $\mathrm{C}$ を通 過するNPR が最も大きくなっている場合である。この場 

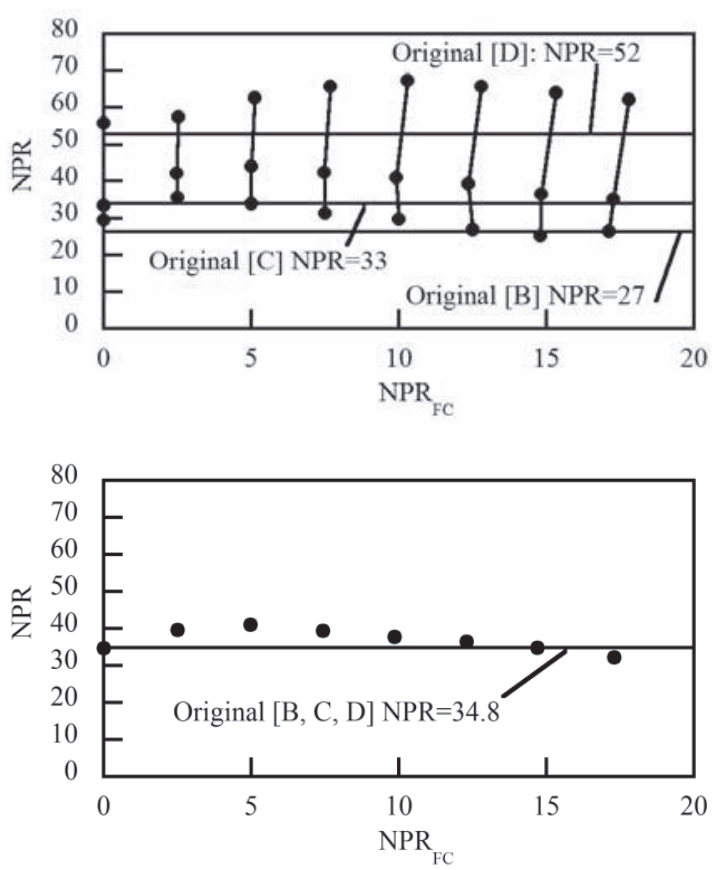

第 15 図各圧力計測点における剥離点通過時の $\mathrm{NPR}_{\mathrm{FC}}$ と $\mathrm{NPR}$ の 関係 $(\mathrm{CFD}$, 上：NPE, 下：PPE，水平線はオリジナル形 状の值)

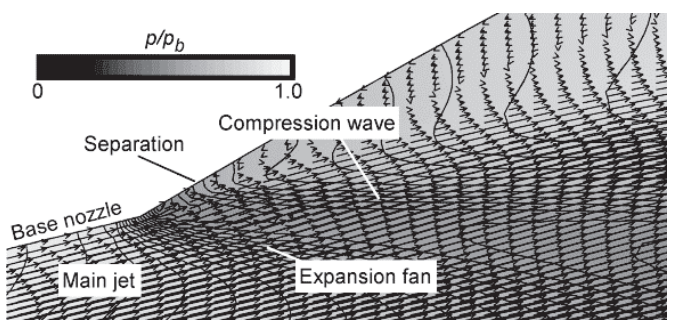

(a) NPEオリジナル形状

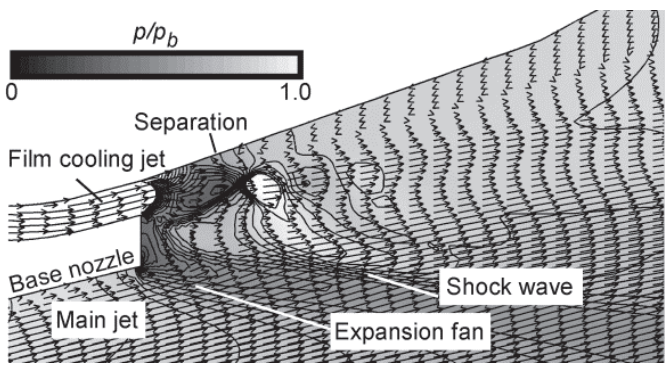

(b) NPR_A10 $\left(p_{\mathrm{FC}}=20 \mathrm{kPa}\right.$ ，遷移時 $\left.\mathrm{NPR}_{\mathrm{FC}}=5.0\right)$

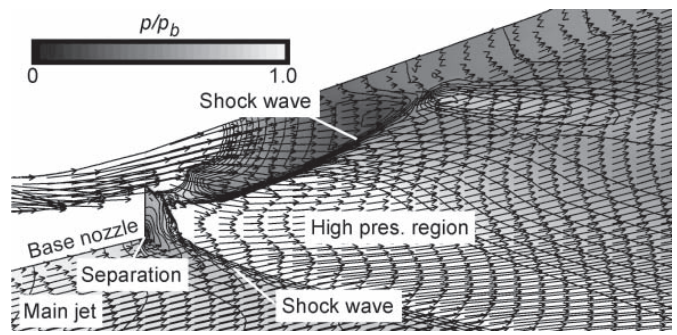

(c) NPR_A10 $\left(p_{\mathrm{FC}}=70 \mathrm{kPa}\right.$, 遷移時 $\left.\mathrm{NPR}_{\mathrm{FC}}=17\right)$

第 16 図 圧力分布および運動量ベクトル $(\mathrm{NPR}=20)$

合には主流は段差の角で剥離している。ただし，実際には 第 12 図の実験結果から, 剝離点の移動が開始（点 $\mathrm{B} に お$

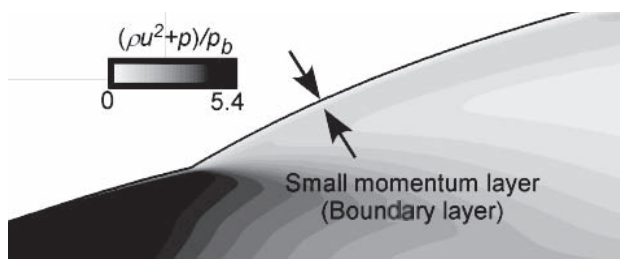

(a) NPE オリジナル形状

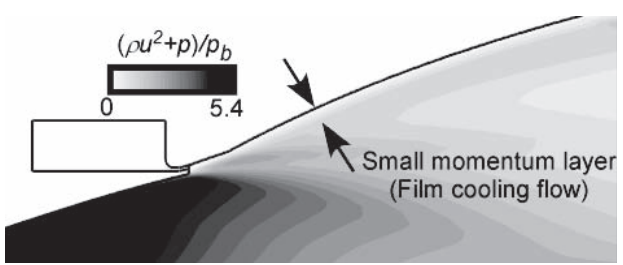

(b) NPR_A10 $\left(p_{\mathrm{FC}}=20 \mathrm{kPa}\right.$ ，遷移時 $\left.\mathrm{NPR}_{\mathrm{FC}}=5.0\right)$

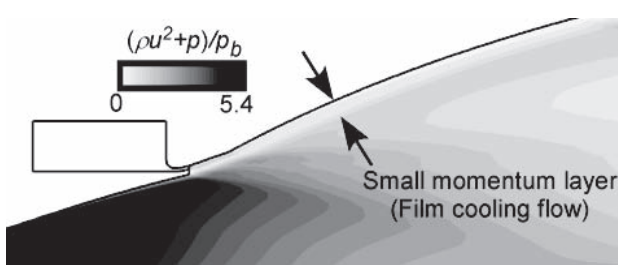

(c) NPR_A10 $\left(p_{\mathrm{FC}}=70 \mathrm{kPa}\right.$ ，遷移時 $\left.\mathrm{NPR}_{\mathrm{FC}}=17\right)$

第 17 図 軸方向運動量の分布 $(\mathrm{NPR}=100)$

ける圧力の低下）する NPR にほとんど差がないことから， フィルム冷却流の入口付近での流れが遷移 NPR を上昇さ せる効果はほとんどないと言える. 第 16 図 (c) では $p_{\mathrm{FC}}=$ $70 \mathrm{kPa}$ でフィルム冷却流を加えており, 第 15 図より, 剝 離点が圧力計測点 $\mathrm{C}$ を通過する NPR の上昇効果が低下し ている場合の流れ場である。このとき, $\mathrm{NPR}_{\mathrm{FC}}$ は 17 とな り, 比較的大きいのでフィルム冷却流は不足膨張の超音速 ジェットとなっている。 そして, 膨張したフィルム冷却流は 主流と干渉し衝撃波が生じ，段差の下流では高圧領域が生 じている。この高圧領域により, 剝離点上流側の圧力が大 きくなるため, 剝離点は低いNPR でも下流へ移動しやす くなっている. 以上のように, $\mathrm{NPR}_{\mathrm{FC}}$ の違いにより, 主 流とフィルム冷却流との干渉の状態が変化し, $\mathrm{NPR}_{\mathrm{FC}}$ が 大きく主流とフィルム冷却流が強く干渉すると運転モード が遷移する NPR を低下させることが判明した，また，フィ ルム冷却流の段差が大きな A17 形状では, フィルム冷却流 の流量も大きく, ここで示した主流との干渉が強く生じる ために運転モードの遷移が行われる NPR が低下したもの と考えられる。

第 17 図は軸方向運動量 $\left(\rho u^{2}+p\right) / p_{\mathrm{b}}$ の分布の比較を示 した図である。壁面近くの軸方向の運動量は噴流の剝離に 大きく影響する。 つまり, 同じNPRであっても, 壁面近く で噴流の運動量が大きければ剝離点はより下流へと移動す る. エクステンション部分に着目して比較するとフィルム 冷却流を加えた場合には, エクステンション部壁面近傍の 運動量が小さな層の幅がフィルム冷却流を加えていないオ リジナル形状と比べて幅が大きくなっていることがわかる.

第 18 図に NPE/PPEノズルのノズル出口の壁面近傍に おける軸方向運動量の半径方向分布を示す. NPEオリジナ 

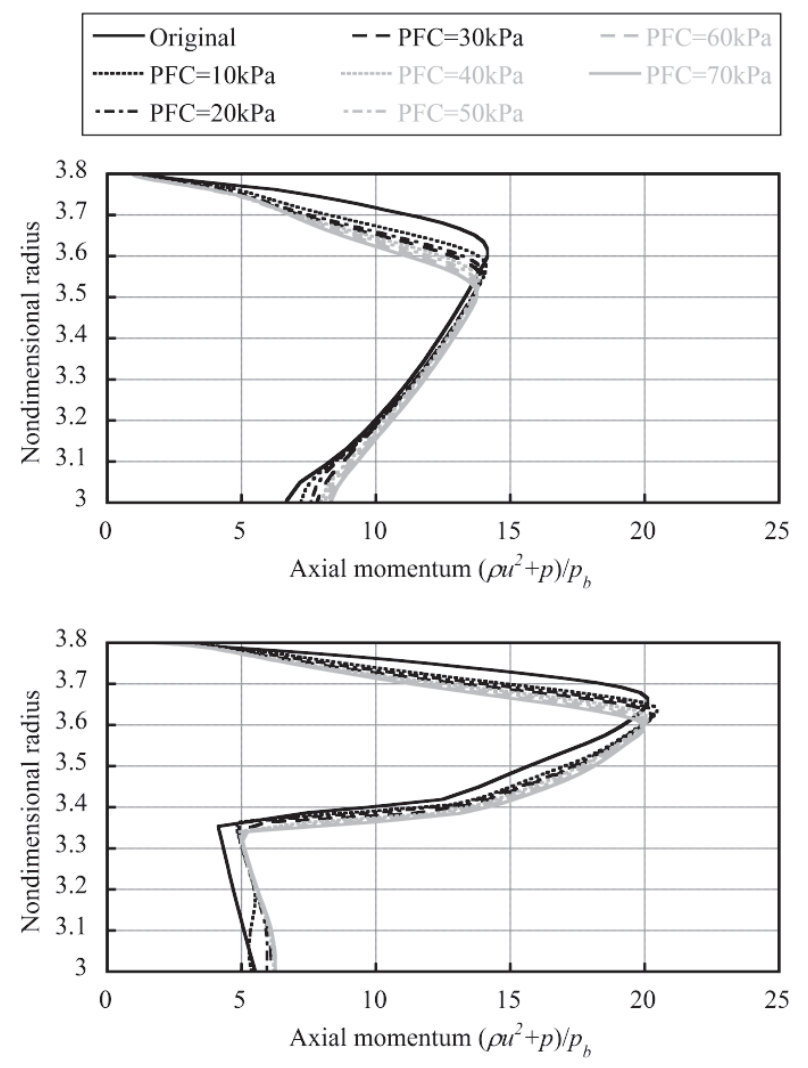

第18図ノズル出口壁面近傍に㧍ける軸方向運動量の半径方向分布 $(\mathrm{CFD}, \mathrm{NPR}=100$, 上 : NPE, 下 : PPE $)$

ル形状においては，運転モードの遷移が理想的な状態より も低いNPR で行われるために，遷移時に推力係数が大き く低下するが, この図からフィルム冷却流により壁面近傍 の運動量が小さくなっていることがわかる，その結果，遷 移はより高いNPR で行われるようになり，推力係数の低 下量も小さくなったと考えられる。 また，フィルム冷却流 の入口全圧はほぼ一定であるため，ノズル壁面に近い部分 での運動量に対する主流の NPR の影響は小さくなる。し たがって, 主流の NPR の変化によって生じる運転モード の遷移は, フィルム冷却流を加えることで, 広範囲の NPR にわたって緩やかに行われると考えられる。一方, PPEノ ズルではノズル出口に近いほど圧力が高くなるため, 第 18 図の下図のように，壁面近傍の軸方向運動量が NPEより もかなり大きいため, フィルム冷却流の影響がほとんど表 れないと考えられる。

\section{4. 結言}

本研究ではデュアルベルノズル内部で接続点からフィル ム冷却流が運転モードの遷移に及ぼす影響について検討す るために，実験と CFD 解析を行った。フフルム冷却流の 影響として実験結果から以下の 3 点が判明した.

・運転モードの遷移が生じるNPR が上昇する。ただし, 最 も効果が大きくなる $\mathrm{NPR}_{\mathrm{FC}}$ が存在し, 過大な $\mathrm{NPR}_{\mathrm{FC}}$ では，低いNPRで運転モードの遷移が始まる。

・運転モードの遷移過程で剝離点の移動が行われる NPR
の範囲が広くなる。

・PPEノズルでは NPE ノズルに比べてフィルム冷却流が 運転モードの遷移に及ぼす影響は小さい.

これに対して, CFD 解析結果からそのメカニズムは次のよ

うにまとめられる.

・ $\mathrm{NPR}_{\mathrm{FC}}$ の違いによって接続点付近での主流とフィルム冷 却流との干渉状態が変化する．特に過大な $\mathrm{NPR}_{\mathrm{FC}}$ では, 干渉部に高圧領域が形成され，運転モードの遷移 NPR が低下する原因となる。

・フィルム冷却流を加えることで, エクステンション部壁 面近傍の軸方向運動量が減少し, 剝離点の移動が広範囲 の NPR にわたって徐々に行われるようになる。このた め, 遷移が完了するまでの NPR は, オリジナル形状に 比べて大きくなる.

・PPEノズルでは NPEノズルに比べて壁面付近の圧力が 高いために, 主流が持つ軸方向運動量が大きく, フィル ム冷却流の効果が小さくなる.

\section{参 考 文 献}

1) Horn, M. and Fisher, S.: Dual-Bell Altitude Compensating Nozzles, NASA-CR-194719, 1994.

2) Sato, M., Moriya, S., Tadano, M., Masuoka, T. and Yoshida, M.: Experimental Study on Transitional Phenomena of Extendible Nozzle, AIAA Paper 2007-5471, 2007.

3) Tomita, T., Kumada, N. and Ogawara, A.: A Conceptual System Design Study for a Linear Aerospike Engine Applied to a Future SSTO Vehicle, AIAA Paper 2010-7060, 2010.

4) Hagemann, G., Frey, M. and Manski, D.: A Critical Assessment of Dual-Bell Nozzles, AIAA Paper 97-3299, 1997.

5) Martelli, E., Nasuti, F. and Onofri, M.: Thermo-FluidDynamics Analysis of Film Cooling inOverexpanded Rocket Nozzles, AIAA Paper 2006-5207, 2006.

6) Kimura, T., Niu, K., Yonezawa, K., Tsujimoto, Y. and Ishizaka, K.: Experimental and Analytical Study for Design of Dual-Bell Nozzles, AIAA Paper 2009-5149, 2009.

7) 米澤宏一, 山下是知, 辻本良信, 渡邊泰秀, 横田和彦: ロケット 用超音速ノズルの形状が過膨張時の流れの剝離に及ぼす影響, 日 本機械学会論文集 B 編, 71 (2005), pp. 1789-1797.

8) Wada, Y. and Liou, M.: A Flux Splitting Scheme with High Resolution and Robustness for Discontinuities, AIAA Paper 94-0083, 1994.

9) Yoon, S. and Jameson, A.: Lower-Upper Symmetric-GaussSeidel Method for the Euler and Navier-Stokes Equations, AIAA J., 26 (1988), pp. 1025-1026.

10) Spalart, P. R. and Allmaras, S. R.: A One-Equation Turbulence Model for Aerodynamic Flows, La Recherche Aerospatiale, 1 (1994), pp. 5-21.

11) Proshchanka, D., Yonezawa, K., Koga, H., Tsukuda, H., Tsujimoto, Y., Kimura, T., Yokota, K. and Pasini, A.: Control of Operation Mode Transition in Dual-Bell Nozzle with Film Cooling, AIAA Paper 2010-6815, 2010.

12) Proshchanka, D., Yonezawa, K., Koga, H., Yokota, K., Kimura, T., Niu, K. and Tsujimoto, Y.: An Investigation of Flow Fluctuation in Overexpanded Dual-Bell Nozzle, Proc. of the Asian Joint Conference on Propulsion and Power, 2010, pp. 256-263.

13) Menter, F. R.: Two-Equation Eddy-Viscosity Turbulence Models for Engineering Applications, AIAA J., 32 (1994), pp. 269-289.

14) Stark, R. H. and Wagner, B. H.: Experimental Flow Investigation of a Truncated Ideal Contour Nozzle, AIAA Paper 2006-5208, 2006. 